\title{
Mending Wall: A Study of Restorative Justice in George R. R. Martin's A Song of Ice and Fire and Tales of Dunk and Egg
}

\author{
Rohani, S. ${ }^{1}$, Abootalebi, H. ${ }^{2}$ \\ ${ }^{1,2}$ English Literature, Lorestan University, Lorestan, IRAN \\ e-mails: sia.lone@yahoo.com; abootalebi2010@gmail.com
}

\begin{abstract}
The current paper deals with the nature of justice in George R. R. Martin's novel series A Song of Ice and Fire (1996- ) and Tales of Dunk and Egg (1998- ) under the light of Daniel Van Ness' theory of restorative justice. This brand of justice is famed for its strong emphasis on the welfare of both parties (that is, victim and offender) in the process of passing judgment, its manner of determining criminal restitution which usually involves conferences, gatherings and community service, and more importantly, its aversion to 'punishment' at all costs. In the title-mentioned works, it will be argued, however, George R. R. Martin depicts a world which shows extreme prejudice against most levels and forms of crime, an attitude which not only fails to heal the damage done by the criminal, but also results in even more damage.
\end{abstract}

Keywords: Daniel Van Ness; restorative justice; community service; George R. R. Martin; A Song of Ice and Fire; Tales of Dunk and Egg.

\section{INTRODUCTION}

The word 'justice', the Longman Dictionary of Contemporary English defines as: a) the system by which people are judged in courts of law and criminals are punished; b) fairness in the way people are treated; and c) the quality of being right and deserving fair treatment. The same source describes the word 'just' as something that is: a) morally right and fair; and b) deserved by someone. Taken together, a common understanding of the concept of 'justice' involves the terms 'law', 'crime', 'punishment', 'fairness', 'equality' and 'rightness'.

Among the many approaches to justice, there is one method that is recognized for its focus on 'restoration', on healing the damage done by the criminal to the victim rather than merely punishing the offender, thereby earning the name 'restorative' (or reparative) justice. Proponents of this brand of justice speak most openly against retributive justice, an approach known for its focus on punishment and just desert. According to Lucia Zedner (1994) in her essay Reparation and Retribution: Are They Reconcilable?, followers of retributive justice pay little heed to the concepts of "public protection, reparation and reform of the offender." Moreover, she maintains, retributive justice often passes judgment on the criminal "without reference to the offender's past record," overlooking the social background of the criminal and thus failing to recognize the real reasons behind the crime. Jon'a F. Meyer (2015) also criticizes just desert theory in "Retributive Justice", calling it an "outdated" philosophy which "does not address any underlying issues that may have led to the crimes in the first place." ( $p$. 35)

Restorative justice, on the other hand, aims to "satisfy the parties, and the way to do that include[s] making things right by repairing the damage to those parties, whether the damage was physical, financial, or relational" (Van Ness, 2010, p. 6). Advocates of restorative justice achieve this goal by "actively involve[ing] victims and offenders in the process of reparation and rehabilitation" (p. 22). Their true purpose, therefore, is not punishing criminals, but rather to "restore a community that had been sundered by crime." (p. 8)

George R. R. Martin is a celebrated American writer of science fiction, horror and fantasy stories. Universally praised for his ongoing historical fantasy series A Song of Ice and Fire, which has recently been adapted to a TV series by HBO channel, Martin's characteristic use of dark atmosphere, clever dialogues and engaging plots won him lasting fame as well as an undisputed place among the greatest writers of the twenty-first century. 
It is hard not to speak about justice when dealing with George R. R. Martin's fantasy series A Song of Ice and Fire and Tales of Dunk and Egg. Set in the fictional, medieval world of Westeros, Martin's tales revolve around the struggles of a number of powerful Houses in a war-torn land to claim the coveted Iron Throne, the symbolic capital of power in the Seven Kingdoms. The ongoing series engages in a number of controversial themes, one of the most prominent of which is justice.

In his novel series A Song of Ice and Fire and Tales of Dunk and Egg, Martin stages several notable situations where justice needs to be served by the local lords or ladies. In A Game of Thrones, the first novel in A Song of Ice and Fire, Tyrion Lannister, the highborn son of the powerful Lord Tywin, is wrongly accused by Catelyn Stark of having staged the assassination of her son Bran. Catelyn arrests Tyrion and takes him to the Eyrie, where they hold a court trial to discuss his crime. Being the son of one of the most influential lords of the Seven Kingdoms, Tyrion is allowed to attend his trial and speak in his defense, even being granted the choice of trial by combat. In The Hedge Knight, the first novella in Tales of Dunk and Egg, the lowborn knight Ser Duncan defends the life of a puppeteer girl from the hands of the spoiled Prince Aerion Targaryen, beating the prince brutally before being arrested and cast to a dungeon. Here, however, the lowborn Ser Duncan is not allowed to attend his own trial, and is only summoned to court after his verdict has been passed. In The Sworn Sword, the second novella in the Dunk and Egg series, a dispute over the right to build a dam on the Chequy Water River spurs the knight Ser Bennis to injure a peasant from the neighbouring land of Coldmoat, an action that threatens to bring about a border war between Lady Rohanne Webber and Ser Eustace Osgrey. Rather than allowing the quarrel to end with a few silver coins, however, Lady Webber insists on inflicting a matching wound on Ser Bennis as a punishment for his indiscretion, an attitude which further pushes the two sides into conflict. In the end, the matter is solved not by violence, but through an unlikely marriage between Ser Eustace and Lady Rohanne, who finally come to set aside their enmities.

Martin's treatment (and, perhaps, criticism) of justice throughout the series is expressed through the characters that inhabit the world of the novels, through dialogues, thoughts and the overall system of justice and the way it is practiced in Westeros. As will be discussed in the following sections, the world of Westeros heavily follows a non-restorative system of justice with no tolerance for any form of crime, an attitude which does not help reduce the damage done by the criminals, but it will also help further the damage by punishing all crimes with extreme severity. This stark intolerance towards crime as well as the vindictive approach to justice in Westeros resembles the practice of justice in the real world today. Van Ness (2010) argues that the justice system in the past required the offenders and their families "to settle accounts with victims and their families in order to avoid cycles of revenge and violence," (pp. 7-6) a tradition which unfortunately "fell into disrepute among criminal justice policymakers in the latter decades of the twentieth century" (p. 3). The same fate seems to have befallen the practice of justice in Westeros. During the Age of Heroes, the offenders were required to pay the "blood price", which was a financial sum paid in exchange for the losses and damages they inflicted upon their victims (Martin, 2003 , p. 59). The later ages of Westeros, however, started to view the blood price as an outmoded style of justice, favoring instead a harsher method which closely resembled the "eye for an eye" approach.

\section{RESTORATIVE JUSTICE}

Tony Marshall (1999), in his essay Restorative Justice: An Overview, provides a definition for restorative justice: restorative justice is a process whereby parties with a stake in a specific offence collectively resolve how to deal with the aftermath of that offence and its implications for the future (p. 8). According to Marshall, the first notable difference between restorative justice and other more traditional methods of justice is that, unlike the latter which insists on punishing criminals and treating them as outsiders, the former insists on the role of both victim and offender in what they call a 'healing' process, in which both parties help each other in repairing the harm and restoring the criminal back to a contributing member of society.

John Braithwaite's (2002) preface to his book Restorative Justice \& Responsive Regulation opens as follows: For informal justice to be restorative justice, it has to be about restoring victims, restoring offenders, and restoring communities as a result of participation of a plurality of stakeholders. (vii)

\section{DANIEL VAN NESS AND HIS RESTORATIVE JUSTICE PROGRAMME}

Daniel Van Ness is a prominent theorist of restorative justice who has been advocating this brand of justice for thirty years. Influenced by Howard Zehr and Mark Umbreait, Van Ness has produced numerous seminal works regarding restorative justice, co-authoring with such figures as Karen Heetderks Strong and Gerry Jognstone. 
According to Daniel Van Ness and Karen Heetderks Strong (2010) in Restoring Justice: An Introduction to Restorative Justice, the process of 'restoration' takes place in a number of steps: encounter, amends, inclusion and reintegration. During the 'encounter' step, the criminal and the victim are asked to meet in person (usually in a court) so that the victims might "address the sentencer (usually the judge) about the impact of the crime on their lives" (p. 65). In the 'amends' step, the criminal is encouraged to compensate for his crime by "taking steps to repair the harm caused" (p. 84). The 'inclusion' step ensures that both victim and offender are given "the opportunity for direct and full involvement... in the procedures that follow a crime" (p. 119). Ultimately, the 'reintegration' step begins, which involves a series of procedures that "help both victims and offenders re-enter their communities as whole, productive, contributing members" (p. 98).

One of the most effective ways to achieve such goals is 'community service'. According to James Dignan (2005) in his Understanding Victims:

Community service may involve 'the community' in determining the work that should be performed by offenders (since the projects themselves are frequently demand led and respond to local need), and may often benefit the community against whom the offences may have been committed. It can also be 'tailored' to the requirements of an individual offender (by relating the project to the offender's particular skills or interests, for example). All of these elements are consistent with restorative justice principles of repairing the harm caused by an offence, engendering a sense of accountability on the part of offenders and seeking their 'reintegration' into the law-abiding community where possible (p. 109).

Daniel Van Ness (2003), in Proposed Basic Principles on the Use of Restorative Justice, contends that restorative programs such as community service are "designed to accomplish reparation of the victim and community, and reintegration of the victim and/or the offender" (p. 166). Convicted criminals are required to work for certain agencies depending on the nature of their crimes as a way of repenting for their deeds, which would in turn reduce their sentence. As Jim Dignan (2003) in Towards a Systemic Model of Restorative Justice, puts it community service can be:

conceptualised either in a straightforwardly reparative manner as a more constructive and meaningful undertaking that is more closely related to the original offence; or as a potentially restorative or reintegrative intervention, for example where the task is related to the offender's skills or interests, or is intended to reinforce the offender's sense of self-esteem by providing a meaningful and worthwhile service to others (pp. 149-50).

\section{GEORGE R. R. MARTIN'S WESTEROS}

The system of laws in the world of Westeros follows a strictly retributivist approach to justice, meaning that most forms and degrees of crime are responded with extreme prejudice. Thieves lose a finger, rapists lose their manhood, while murderers and traitors are either sentenced to life imprisonment or executed, depending on the circumstances. Those who avoid execution, however, are instead forced to join the Night's Watch to serve the remainder of their lives guarding the realm against threats from beyond the Wall. Despite Westeros' strictly retributivist approach to justice, however, the concept of the Night's Watch loosely resembles the idea of 'community service', which has its roots in restorative justice.

\section{THE WALL AND THE NIGHT'S WATCH}

The Wall is an ancient, long structural border north of Westeros that separates the realm from the perilous lands far to the north. It is guarded by men of the Night's Watch, a brotherhood sworn to protect the realm from the threat of Others, White Walkers and wildlings who dwell beyond the Wall. Members of the Night's Watch are required to serve the rest of their lives at the Wall, where every attempt at desertion is answered with death: Once you have taken the black, there is no turning back. The penalty for desertion is death. (Martin, 1996, p. 352). Men of the Night's Watch are also forbidden to take wives, father children or own any land:

A man of the Night's Watch lives his life for the realm. Not for a king, nor a lord, nor the honor of this house or that house, neither for gold nor glory nor a woman's love, but for the realm, and all the people in it. A man of the Night's Watch takes no wife and fathers no sons. Our wife is duty. Our mistress is honor. And you are the only sons we shall ever know (p. 352).

Despite following some sort of hierarchical structure whereby the Lord Commander is the final arbiter, the Night's Watch still benefits from a certain level of equality which is seldom seen elsewhere in Westeros. As such, members of the Night's Watch are all considered brothers despite their former social or political status, or the prestige of the House they come from: 
You came to us outlaws, poachers, rapers, debtors, killers, and thieves. You came to us children. You came to us alone, in chains, with neither friends nor honor. You came to us rich, and you came to us poor. Some of you bear the names of proud houses. Others have only bastards' names, or no names at all. It makes no matter. All that is past now. On the Wall, we are all one house (p. 352).

Although the institution was originally founded with the sole intention of guarding the realm against threats from beyond the Wall, the Night's Watch of the later ages slowly derailed from its primary purpose and became a gathering of all sorts of criminals and outlaws who were often given the choice between death and joining the Night's Watch. In their companion book The World of Ice and Fire, Elio Garcia and Linda Antonsson (2014) point out to this fact through the words of Maester Yandel (the alleged fictional author of the book): Some argue that the Wall serves as a useful way of ridding the realm of murderers, rapers, poachers, and their ilk. (p. 509). As a result of this degeneration, serving the Night's Watch in its current state shares a number of similarities with community service, which is also an institution that aims at criminal restitution.

One of the most obvious affinities between the Night's Watch and community service is their shared criminal population. Both institutions are mainly composed of outlaws and outcasts who have no place in their society. As Tyrion Lannister aptly tells Jon Snow: the Night's Watch is a midden heap for all the misfits of the realm... Sullen peasants, debtors, poachers, rapers, thieves, and bastards like you all wind up on the Wall. (Martin, 1996, p. 87). And both serve as an alternate way for a criminal to wash away his sins and start his life with a clean slate:

At evenfall, as the sun sets and we face the gathering night, you shall take your vows. From that moment, you will be a Sworn Brother of the Night's Watch. Your crimes will be washed away, your debts forgiven. So too you must wash away your former loyalties, put aside your grudges, forget old wrongs and old loves alike. Here you begin anew (p. 352).

\section{ARGUMENTATION}

In the subsequent section, Westerosi law system, the Night's Watch and community service will be put to comparison in the light of Daniel Van Ness' four-step procedure of criminal restitution (encounter, amends, inclusion and reintegration) in an attempt to measure the efficiency of the Westerosi law and the Night's Watch in restoring criminals to healthy citizens.

\section{ENCOUNTER}

In Westeros, when an offender is detained for his crime, he is taken to his liege lord, who would thereby sit in judgment to determine the outlaw's verdict. Unless the victim is highborn, this process is usually done without his attendance. Also perpetrating crimes in Westeros is mainly seen as violation of the king's peace, not the individual's rights, an attitude that is especially common in retributive justice. Thus, here, the first step to restorative justice - encounter - is largely neglected, thereby depriving the victim and the offender of the opportunity to meet in person to discuss the damage caused because of the crime. The best instance of this approach is seen in the second of a series of novellas called Tales of Dunk and Egg, which share their setting with $A$ Song of Ice and Fire while happening about a century prior to the latter's beginning. During the second novella The Sworn Sword, a hedge knight by the name of Ser Bennis, who is in service of Ser Eustace Osgrey of Standfast, physically injures a peasant from the contiguous land of Coldmoat when he and his companions refuse to tear down a recently-built dam that denies Ser Eustace's lands access to water. To avoid the tension from sparking into a border war, Ser Duncan suggests that the peasant be paid in silver for the injury, only to be refused by the Lady of Coldmoat, who insists that Ser Bennis be turned over to her so that she can punish him herself:

Duncan: "Why not send for that man that Bennis cut, and ask him if he'd sooner have a silver stag or Bennis in a sack?"

Rohanne: "Oh, he'd pick the silver, if he couldn't have both. I don't doubt that, ser. It is not his choice to make. This is about the lion and the spider now, not some peasant's cheek. It is Bennis I want, and Bennis I shall have. No one rides onto my lands, does harm to one of mine, and escapes to laugh about it" (Martin, 2003, p. 59).

Here, Lady Webber's brand of justice is clearly not restorative (which aims directly at the welfare of both parties involved) but extremely retributive (with its strong emphasis on punishment). And so, the Lady of Coldmoat acts upon the despoiled honor of her house, not that of her people.

\section{AMENDS}

It is a well-known fact in Westeros that those who have been branded as criminals or traitors are given the opportunity to avoid severe (even capital) punishment by joining the Night's Watch and serving there for the rest of their lives, restoring their lost 
honor in the process. Jon knew that other men accused of treason had been allowed to redeem their honor on the Wall in days past (Martin, 1996, p. 385). This is partly true, and partly false. While it is true that men of the Night's Watch spend the remainder of their lives on the Wall guarding the realm against the threat of Others, White Walkers and wildlings, few people south of the Wall believe that such threats even exist anymore as the last time the Others assaulted Westeros that have happened some eight thousand years ago, thus rendering the Night's Watch efforts at guarding the realm a futile, costly attempt. It is true, of course, that despite what the people of Westeros believe, the Others do exist and are about to invade the Seven Kingdoms once again, but since few people are aware of this fact, their intentions at sending criminals to the Wall deconstructs their own beliefs.

Tyrion Lannister speaks most clearly of this common disbelief in the existence of any threats beyond the Wall when he mockingly tells Jon Snow that the Brothers of the Night's Watch guard the realm against "grumkins and snarks and all the other monsters your wet nurse warned you about. The good part is there are no grumkins or snarks, so it's scarcely dangerous work." (p. 38). This means that, while men of the Night's Watch (offenders) make amends for their crimes, the people of Westeros (victims) do not appreciate the attempt, thereby rendering the second step to restorative criminal restitution - amends virtually pointless because an important part of making amends is the impression it leaves on the victim, making it easier for him to forgive the criminal, and with it, heal the damage.

\section{INCLUSION}

Although not directly stated, the right to attend one's own trial in Westeros is mainly in possession of the highborn class, while the lower class (called the "smallfolk") are given no such right in similar cases. However, the third step to restorative restitution inclusion - must involve the presence of both parties (victim and offender) in the act of restoring the damage and helping the criminal reenter the society, a step which is utterly ignored in Westeros. This discrimination can be seen in two separate occasions where Tyrion Lannister (a highborn) is allowed to attend his trial while Ser Duncan (a lowborn) is not.

In A Game of Thrones, the first volume of A Song of Ice and Fire, Tyrion Lannister, who has been deemed guilty of Bran's failed assassination, is granted the right to be present at his trial in the Eyrie while the court decides his verdict. Being the son of the powerful Lord Tywin Lannister, and therefore a true highborn, Tyrion is given the chance to argue for his innocence, even being granted the right to choose trial by combat. As Tyrion himself reflects: he was highborn, the son of the most powerful lord in the realm, the brother of the queen. He could not be denied a trial. (Martin, 1996, p. 287)

The same thing cannot be said about Ser Duncan, a lowborn hedge knight featuring in the novella series Tales of Dunk and Egg, which also takes place in Westeros. In the first novella, The Hedge Knight, Ser Duncan beats Prince Aerion Targaryen after witnessing the latter brutally attack a puppet girl on a flimsy pretext of treason. Despite being in the right and in full view of dozens of spectators, Ser Duncan is immediately captured and is almost killed, before being saved by the prince's brother. However, in Ser Duncan's case, the knight is not granted the same right that Tyrion enjoyed, and thus he is incarcerated in a dungeon while the royalty alone decide about his fate in his full absence, only summoning him to court after his verdict has been passed. Neither do the royalty ever ask the puppet girl to attend the court to testify against her crime or Duncan's.

Such a case also happens in The Sworn Sword. The peasant whom Ser Bennis injures takes the matter to the Lady Webber, but is nonetheless completely absent during Ser Duncan's parley with the Lady of Coldmoat, or indeed, during the rest of the story. The right of 'inclusion' in Westeros is granted only to the highborn, who comprises only a part of that world's population, therefore negating the concept of 'justice' on the grounds of 'equality'.

\section{REINTEGRATION}

As mentioned earlier, those who join the Night's Watch are given a new life wherein all their past crimes are forgiven, thus being provided with a fresh chance to serve the realm as atonement for their previous wrong deeds. And while it is true that the Night's Watch selflessly serves the realm, from the standpoint of restorative justice, there is one major problem in the process: there is simply no return from the Night's Watch, and with it, no chance for the criminal to return to his society as a new good citizen. According to the 'reintegration' step, however, the criminal, after fully undergoing the restitution process, should be allowed to enter his society again as a new, healthy citizen. This contrast alone puts the Night's Watch severely at odds with restorative restitution, because serving in community service is only a step towards becoming a good, healthy citizen; it is not an end in itself. 
Furthermore, the Night's Watch itself enjoys little to no prestige among the rest of the realm, which in turn makes the process of reintegration even less possible. Lord Commander of the Night's Watch Jeor Mormont once states that "I fear we count for less than nothing in King's Landing" (p. 447). Here, King's Landing, the capital city of Westeros, might as well stand as a metaphor for the Seven Kingdoms.

\section{CONCLUSION}

In a world like Westeros where crime and violence are so intermingled that one cannot tell them apart, the best solution to the problem of crime is not punishing the offenders with the penalty of death or exile, but rather using their abilities to mend the damages they themselves have inflicted upon their society as a form of repenting for their wrongs.

The present study demonstrates that the world of Westeros, as presented by George R. R. Martin in $A$ Song of Ice and Fire and Tales of Dunk and Egg, strictly follows a non-restorative approach to justice and criminal restitution, meaning that those who are branded as outlaws or traitors are deemed as incurable anomalies better being wiped out than being restored back to normality. After comparing the mechanics of Westerosi laws and the Night's Watch with those of community service in the light of Daniel Van Ness' four-step procedure of criminal restitution, it becomes clear that justice and criminal restitution in the world of Westeros operate under the influence of a flawed, biased law system which favors the highborn over the lowborn, as well as following a bastardized version of both restorative and retributive justice.

According to Van Ness' four-step procedure of restorative criminal restitution, Westerosi law lacks in all four fields when dealing with outlaws. Unless both parties are highborn, there is simply no possibility of an 'encounter' between the victim and the offender in order to discuss the damage done during the crime, because the law enforcement interferes with the procedure and steps between the two parties. The only way for the offender to make 'amends' for his crime is to either pay a hefty sum of money - which the criminal usually cannot afford, even if the victim settles for money alone - or joins the Night's Watch which, despite its active role in guarding the realm, is largely deemed as a worthless order, thereby negating its value as a restorative process. The law's interference with the process of criminal restitution also prevents the possibility of 'inclusion' on both the victim's and the offender's part in restoring the damage and helping the criminal return to society as a healthy citizen. Finally, the state of exile in the Night's Watch prevents its members the chance of 'reintegration', of rejoining their society with that clean slate they worked so hard to attain.
All in all, this style of justice in Westeros does not prevent crimes by curing what really ails the society; it instead helps cause even more damage by cutting off a partially infected organ, where it could still be nursed back to health with proper care. This is even more obvious in Martin's novella The Sworn Sword, in which a simple, timely matrimony between Ser Eustace and Lady Rohanne manages to nullify the long-lasting seeds of hatred between their two Houses, preventing an otherwise brutal border war. Thus the hand of friendship accomplishes what a thousand swords could not.

\section{REFERENCES}

Braithwaite, John. (2002) Restorative justice \& responsive regulation. New York: Oxford University Press, Inc.

Dignan, J. (2003). "Towards a systemic model of restorative justice: Reflections on the concept, its context and the need for clear constraints". Restorative justice and criminal justice: competing or reconcilable paradigms? North America: Hart Publishing.

Dignan, J. (2005). Understanding victims and restorative justice. England: Open University Press.

Garcia, Elio and Antonsson, Linda. (2014). A world of ice and fire: The untold history of westeros and the game of thrones. New York: Bantam Books.

Martin, George. R. R. (1998). The hedge knight. USA: Dabel Brothers Productions.

---. (1996). A game of thrones. New York: Bantam Books.

---. (2003). The sworn sword. USA: Dabel Brothers Productions.

Marshall, T. F., \& Great Britain. Home Office (Research, D. a. S. D. (1999). Restorative justice: An overview. London: Home Office, Research, Development and Statistics Directorate.

Meyer, J. F. Retributive Justice.” (2015). In encyclopaedia britannica.retrieved from http://www. Britannica.com/topic/retributive-justice

Van Ness, D. W, Strong, K. H. (2010). Restoring justice: An introduction to restorative justice. New Jersey: Matthew Bender \& Company, Inc.

Van Ness, Daniel. (2003). "Proposed basic principles on the use of restorative justice: Recognising the aims and limits of restorative justice". Restorative justice and criminal justice: Competing or reconcilable paradigms? North America: Hart Publishing.

Zedner, Lucia. (1994). "Reparation and retribution: are they reconcilable?" The Modern Law Review, 57(2), 228-250. 